\title{
Enrichment conditions of Hetaoyuan Formation shale oil in Biyang Depression, China
}

\author{
Fei Shang ${ }^{1}\left[\right.$ : Xinong $X^{2}{ }^{2} \cdot$ Shuifu $\mathrm{Li}^{1}$
}

Received: 20 June 2018 / Accepted: 5 October 2018 / Published online: 11 October 2018

(c) The Author(s) 2018

\begin{abstract}
In this paper, the data of thin section, organic petrology, geochemistry, lithology and porosity were used to investigate enrichment conditions of Hetaoyuan Formation shale oil in the Biyang Depression. The results show the shale oil is a kind of low-maturity oil with medium density and low viscosity, and main factors controlling shale oil enrichment include total organic content (TOC), formation pressure, lithofacies and effective reservoirs. Shales in the fifth organic-rich interval are developed widely with large thickness (reach up to $150 \mathrm{~m}$ ), high TOC content (2.0-4.68\%), better organic matter types (type $\mathrm{I}_{\text {and }} \mathrm{II}_{1}$ ) and appropriate thermal maturity (usually larger than $0.5 \%$ ), which are beneficial to generate much hydrocarbon, and volume expansion causes overpressure in source rock, especially in sections with low hydrocarbon expulsion efficiency due to less fractures. Free hydrocarbons $S_{1}$ values increase with TOC contents, and significant overpressure correlates with the larger OSI $\left(S_{1} /\right.$ TOC $\left.\times 100\right)$ values and porosity. Well-developed calcareous shales and argillaceous shales with silty shale interlayers have better porosity, and effective pores (throat diameters greater than $10 \mathrm{~nm}$ ) contribute to $47.5 \%$ of the total volume.
\end{abstract}

Keywords Shale oil $\cdot$ Hydrocarbon enrichment condition $\cdot$ Overpressure $\cdot$ Lacustrine shale $\cdot$ Biyang Depression

\section{Introduction}

Shale oil is one of the main unconventional resources and has become an important successive exploration frontier. Shale oil refers to liquid hydrocarbons in shale formations which occur in free, adsorbed and dissolved forms, etc., with economic development requiring horizontal drilling and fracturing (Zou et al. 2013). The successful development of shale oil plays in North America has led to active shale oil exploration in China (Nie et al. 2016). Several studies have addressed the concept, sedimentary environment, reservoir characteristics, resource evaluation and development

Xinong Xie and Shuifu Li are the coauthors.

Fei Shang

cug275@163.com

1 Key Laboratory of Tectonics and Petroleum Resources of Ministry of Education, Faculty of Resources, China University of Geosciences, No. 388 Lumo Road, Wuhan, China

2 College of Marine Science and Technology, China University of Geosciences, Wuhan, China techniques, etc., of these resources (Jiang et al. 2014; Zou et al. 2015; Song et al. 2013), and the commercial oil flow has been discovered in Sichuan basin, Ordos basin and faulted basins in eastern China.

In this paper, taking an example from the organic-rich shales of Eocene Hetaoyuan Formation in the Biyang Depression, the enrichment conditions of lacustrine shale oil are discussed based on the analysis of hydrocarbongenerating characteristics, formation pressure, lithological assemblages and associated reservoir features. Results from this study provide reliable geologic bases for lacustrine shale oil exploration in the Biyang Depression.

\section{Geologic setting}

The Biyang Depression, one of the sub-tectonic units in the Nanxiang Basin (Fig. 1a), is a half graben with small area and high hydrocarbon production. It can be divided into three structural units: northern slope, central sag and southern steep slope (Fig. 1b). The main hydrocarbon source rock is the third member $\left(\mathrm{Eh}_{3}\right)$ of Hetaoyuan Formation, and can be subdivided into eight layers from base 
Fig. 1 a Sketch map of China showing location of the Nanxiang Basin; $\mathbf{b}$ structural units of the Biyang Depression and location of the study area and key wells; c generalized stratigraphic columns of the Biyang Depression and the lithologic sequence of ORI 5

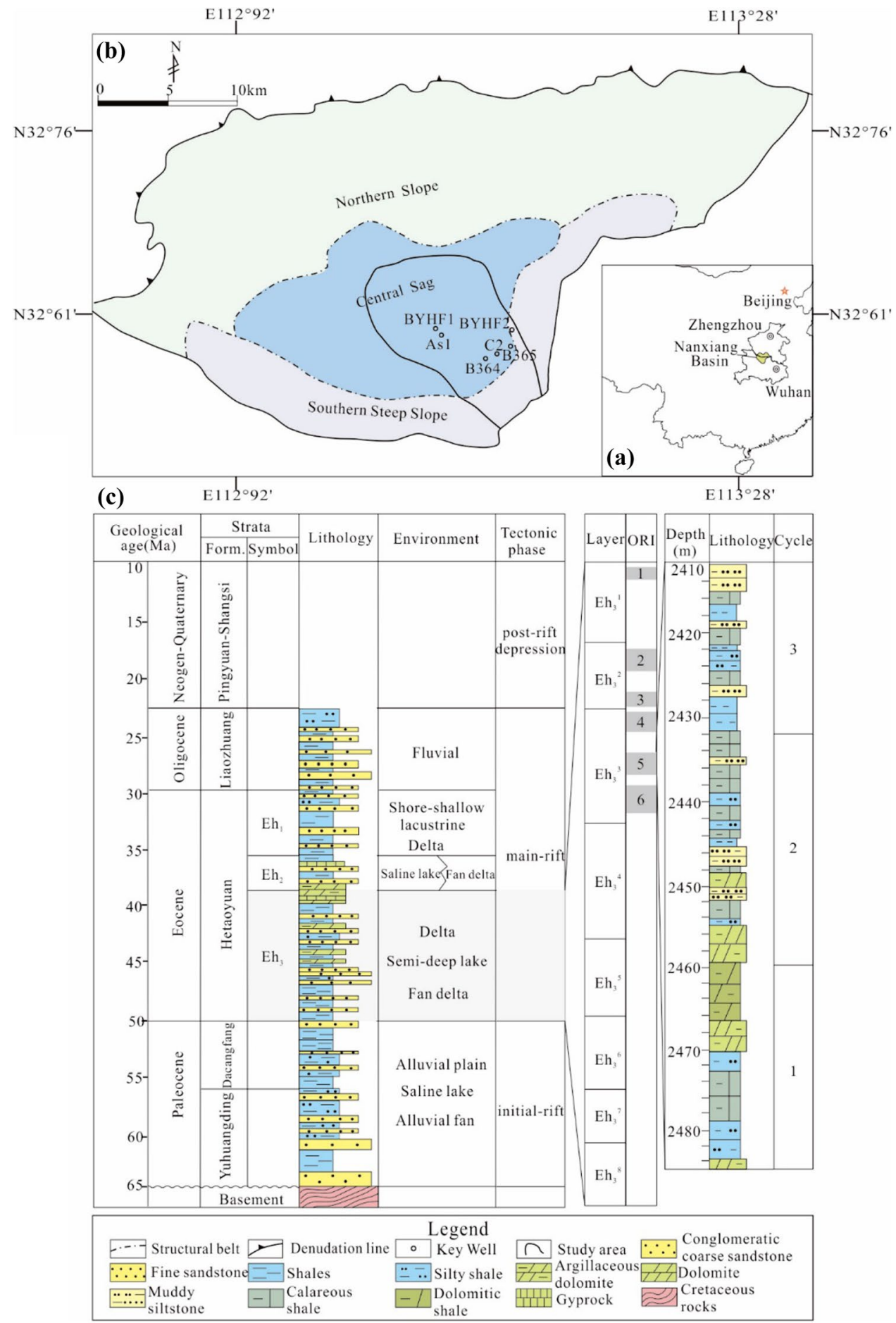

to top. The upper three layers $\left(\mathrm{Eh}_{3}{ }^{3}-\mathrm{Eh}_{3}{ }^{1}\right)$ can be further divided into six organic-rich intervals (ORIs) with TOC contents greater or equal to $2 \%$ (Fig. 1c), which are the main exploration targets for shale oil. The ORI 5 has been proved to be the favorable one by drilling wells BYHF 1 and Cheng 2 with the daily oil production up to $23.6 \mathrm{~m}^{3}$.

\section{Samples and methods}

A total of 36 core samples are collected from ORI 5 of well BYHF 1 with the depth of 2415.72-2450.15 m. These samples are subjected to maceral studies, TOC measurements, Rock-Eval pyrolysis and organic geochemical analysis. A 
subset of six samples is subsequently selected for mercury injection capillary pressure (MICP) analysis. Two shale oil samples are collected from wells BYHF 1 and BYHF 2 for physical properties and geochemical analysis. The TOC contents, organic petrology and geochemical analysis were performed at experimental research center of the Wuxi Research Institute of Petroleum Geology of SINOPEC. The TOC content was measured by Leco CS200 Carbon/Sulfur Analyzer, and organic matter was studied under reflected light at a magnification from 200 to $500 \times$ using polished blocks. Maceral composition was identified and assessed semi-quantitatively. Gas chromatography (GC) analysis of the saturated hydrocarbon was performed using an Agilent7890A gas chromatograph equipped with a 50-m DB-Petro column $(0.20 \mathrm{~mm}$ I.D. and $0.50 \mu \mathrm{m}$ film thickness) as well as flame ionization detector (FID). The oven temperature was programmed from 80 to 300 at $3{ }^{\circ} \mathrm{C} / \mathrm{min}$ and held at $300{ }^{\circ} \mathrm{C}$ for $20 \mathrm{~min}$. The MICP tests were performed using a Mercury Injection Porosimeter (Micromeritics AutoPore IV 9510) at University of Texas, Arlington, USA.

\section{Results and discussion}

\section{Shale oil characteristics}

The extracts of the two shale oil samples are medium oil with density of 0.8694 and $0.8748 \mathrm{~g} / \mathrm{cm}^{3}$, and surface viscosity of 15.76 and $15.58 \mathrm{mPa}$ s, similar to the normal crude oil. Gas chromatographic analysis of the saturated hydrocarbon fractions of the obtained extracts indicates $n$-alkanes ranging from $n$ - $\mathrm{C}_{11}$ to $n$ - $\mathrm{C}_{39}$ (Fig. 2), and $n$-alkanes with weak
Fig. 2 The saturated hydrocarbon gas chromatography analyses of shale oil from well BYHF 1 (a) and well BYHF 2 (b) in Biyang Depression
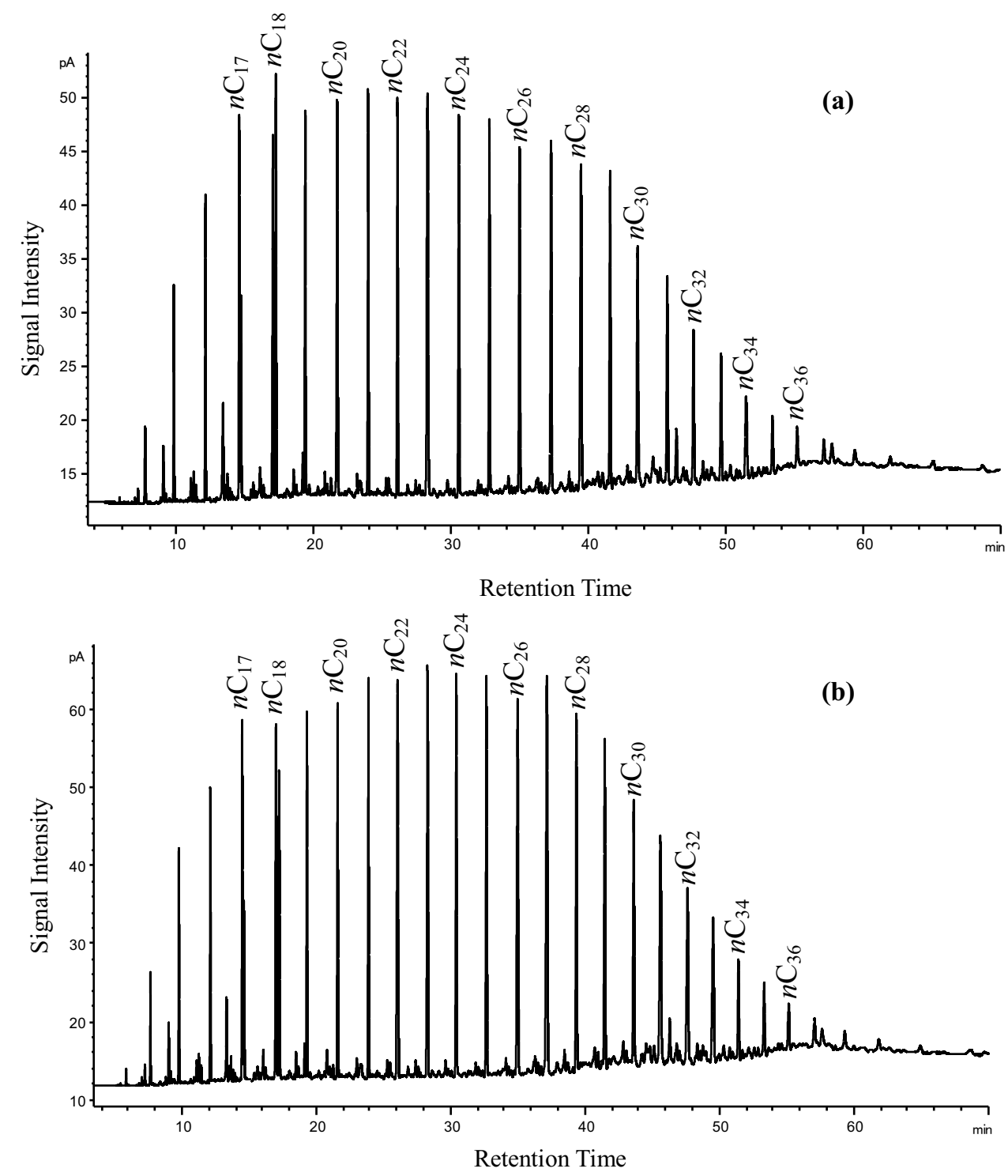
odd-even predominance between $n-\mathrm{C}_{21}$ and $n$ - $\mathrm{C}_{27}$ indicate low maturity of crude oil.

\section{Sources and contents of organic matter}

Variations in the organic petrologic composition and biomarker (association) of shales may reflect origin of organic matter. Optical microscopy indicates organic-rich shales contain abundant sapropelinite (41.5-92.5\%, Avg. 74.4\%) (Fig. 3), consisting of lamalginite, structured remains of algae and bituminite. Lamalginites often exhibit moderate yellow fluorescence, and distribute parallel to beddings with lamellar form, or interbedded with microlayered clay minerals (Fig. 4a). Structured remains of algae fluoresce strongly, and appear to be larger than lamalginite with clear internal structure. They often exhibit pelletoid and distribute along the bedding with local concentration (Fig. 4b), and show cell structure under magnification (Fig. 4c). The content of liptinite ranges from 2.5 to $52.3 \%$ (Avg. 14.3\%), with the dominant components of sporophore and liptodetrinite (Fig. 4d). Vitrinite generally constitutes from 2.4 to $42.8 \%$, mainly including vitrodetrinite and phyllotelinite (Fig. 4e). Inertinite is a minor component, ranging from 0 to $3.7 \%$. Clay material, pyrite and terrigenous debris are also recognized (Fig. 4f). The existence of the inertinite only in the upper part of ORI 5 may be associated with depositional environment. During the upper part of ORI 5 deposition, the paleoclimate changed from hot-arid to humid/warm climate and water salinity decreased (Shang et al. 2015), and the unstable stratified water benefits increasing oxygen fugacity and the transformation from vitrinite to inertinite. According

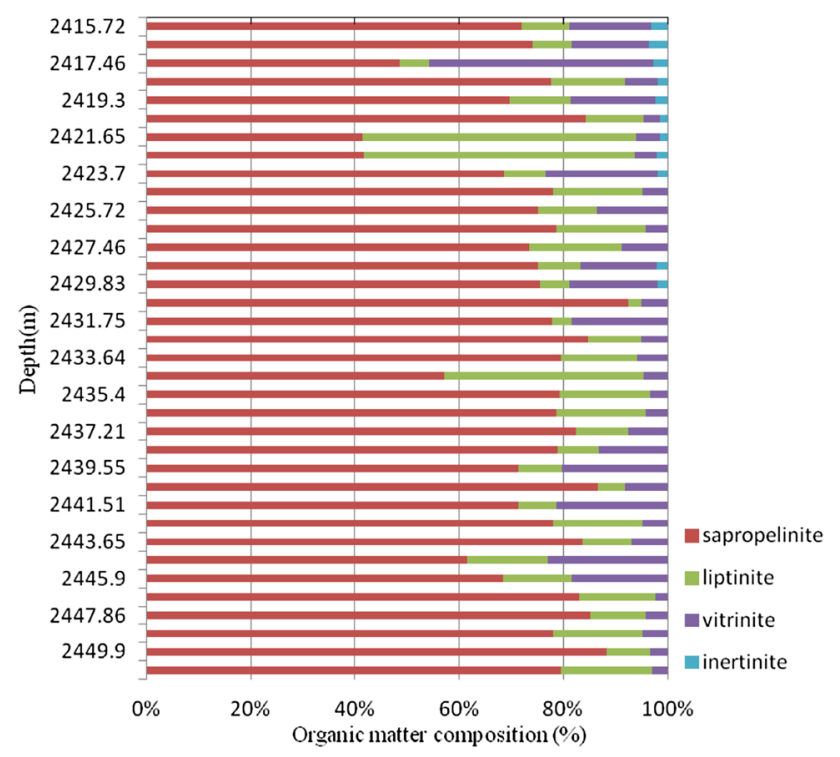

Fig. 3 Composition of organic matter in ORI 5. Sapropelinite is the dominant form of organic matter to the guidelines proposed by Meinschein and Huang (1981), a ternary diagram of regular steranes $\left(\mathrm{C}_{27}-\mathrm{C}_{29}\right)$ for measured samples is presented (Fig. 5a), suggesting higher plants dominated source rocks, followed by aquatic organisms. As a note, the relative higher $\mathrm{C}_{29}$ regular sterane of few samples is ascribed to the combined impact of higher plants and algae, and $\mathrm{C}_{29}$ regular sterane may be detected without higher plants input to the sediments. Therefore, the organic maceral analysis is reliable and the organic sources are mixed with algae and terrigenous organisms.

ORI 5 of well BYHF 1 presents a burial depth of $2395.7-2478.1 \mathrm{~m}$ with $R_{\mathrm{o}}$ values of $0.58-0.59 \%$ (Table 1 ), indicating shales reached the oil generation window with low maturity. The values of TOC and $S_{1}+S_{2}$ of the samples range from 0.48 to $7.64 \%$ (Avg. 2.86\%) and 0.95 to $50.50 \mathrm{mg} / \mathrm{g}$ (Avg. $15.16 \mathrm{mg} / \mathrm{g}$ ), respectively. The bitumen "A" contents of most samples are larger than $0.2 \%$. Generally, $R_{\mathrm{o}}$ values in the study area are larger than $0.6 \%$, and increase from northwestern to southeastern (Fig. 5b). The retention oil content $\left(S_{1}\right)$ of majority samples correlates positively with TOC values (Fig. 5c), suggesting shale oil abundance is partly affected by organic matter content. While the different change trends of $S_{1}$ rising slowly with the increase of TOC value and rising rapidly with low TOC (samples in circles of Fig. 5c) may be due to relatively high hydrocarbon expulsion efficiency and the external migrated hydrocarbon impact, respectively ( $\mathrm{Li}$ et al. 2016). By applying method of multivariate regression analysis, the thickness and average TOC contents of ORI 5 in 30 wells are predicted (Shang et al. 2016). The largest thickness of ORI 5 can reach $150 \mathrm{~m}$, mainly distributed in the center of the deepest sag (Fig. 5d). The average TOC contents range from 2.0 to $4.68 \%$, and gradually decrease from center to edge of the deepest sag (Fig. 5e). All of these indicate good quality of lacustrine shale with large thickness developed in the deepest sag, and the large TOC values and oil generation volume result in much hydrocarbon retention and good shale oil potential.

\section{Overpressure}

The uncompacted source rock with overpressure usually has higher porosity, corresponding to relatively lesser density logging data and larger acoustic time data, which are believed to reflect changes in formation pressure. Figure $6 \mathrm{a}, \mathrm{b}$ show that acoustic time data from $\mathrm{H}_{3} \mathrm{III}$ to $\mathrm{H}_{3} \mathrm{I}$ in wells BYHF1 and B364 fall in the right area of trend line, reflecting overpressure exists in ORIs. The calculated average formation pore pressures of ORI 5 in 30 wells in the study area range from 1.01 to 1.40 using the method of equivalent depth, and the distribution of pressure is consistent with the distribution of the thickness and TOC contents (Fig. 6c), indicating hydrocarbon generation leads 

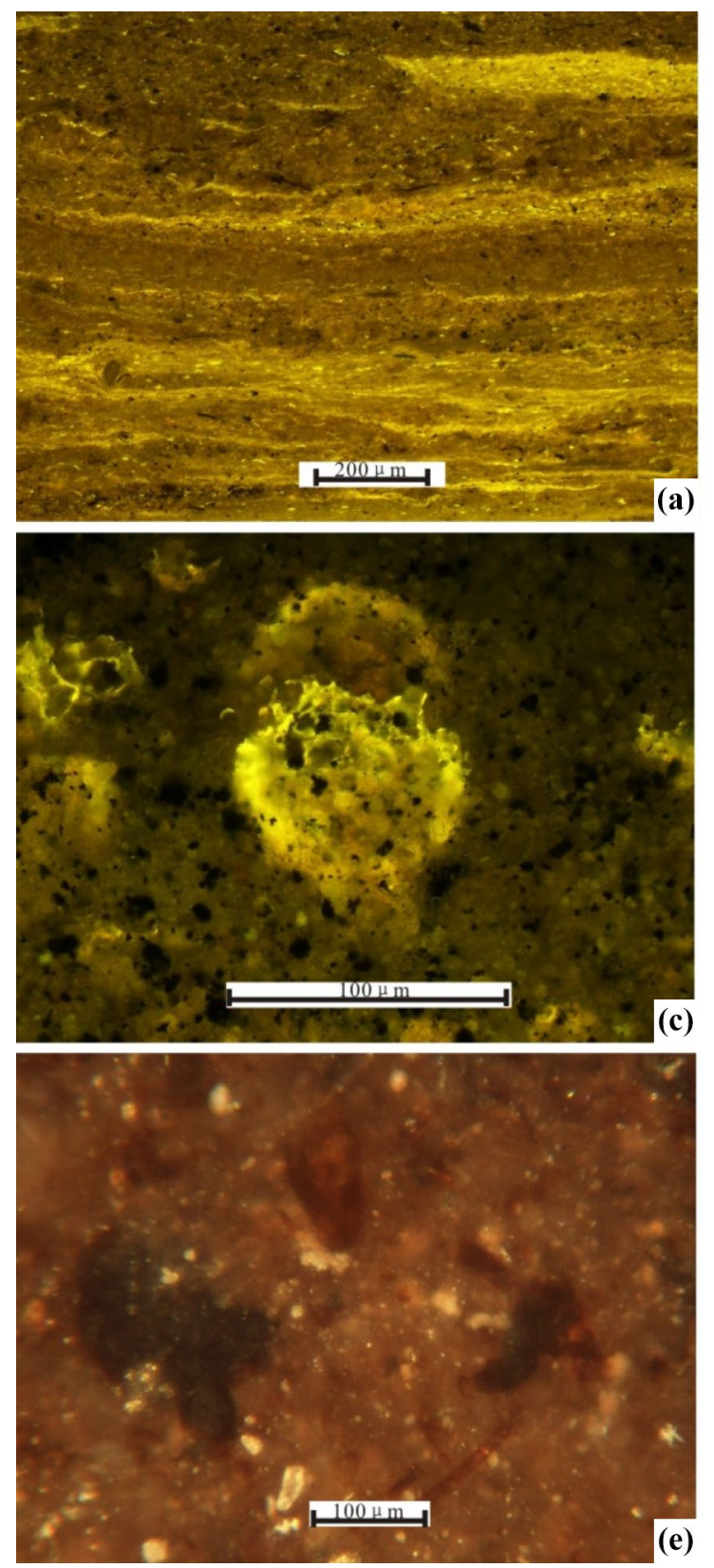

Fig. 4 Photomicrographs of organic matter from ORI 5 of well BYHF 1. a Lamalginite fluorescing moderate yellow with lamellar form, $2417.46 \mathrm{~m} ; \mathbf{b}$, c bright yellow fluorescence-structured remains of algae associated with clay minerals, and show cell structure under

to overpressure. Meanwhile, there exists good correlation between significant overpressure, and the larger OSI values and porosity in ORI 5 (Fig. 6d), further demonstrating the overpressure contributes to generate microfractures along contact areas of various lithofacies and surfaces of stress concentration (Liu et al. 2012), increasing the migration and storage space of shale oil. In summary, the overpressure area is favorable for shale oil enrichment due to high oil retention amount and porosity.
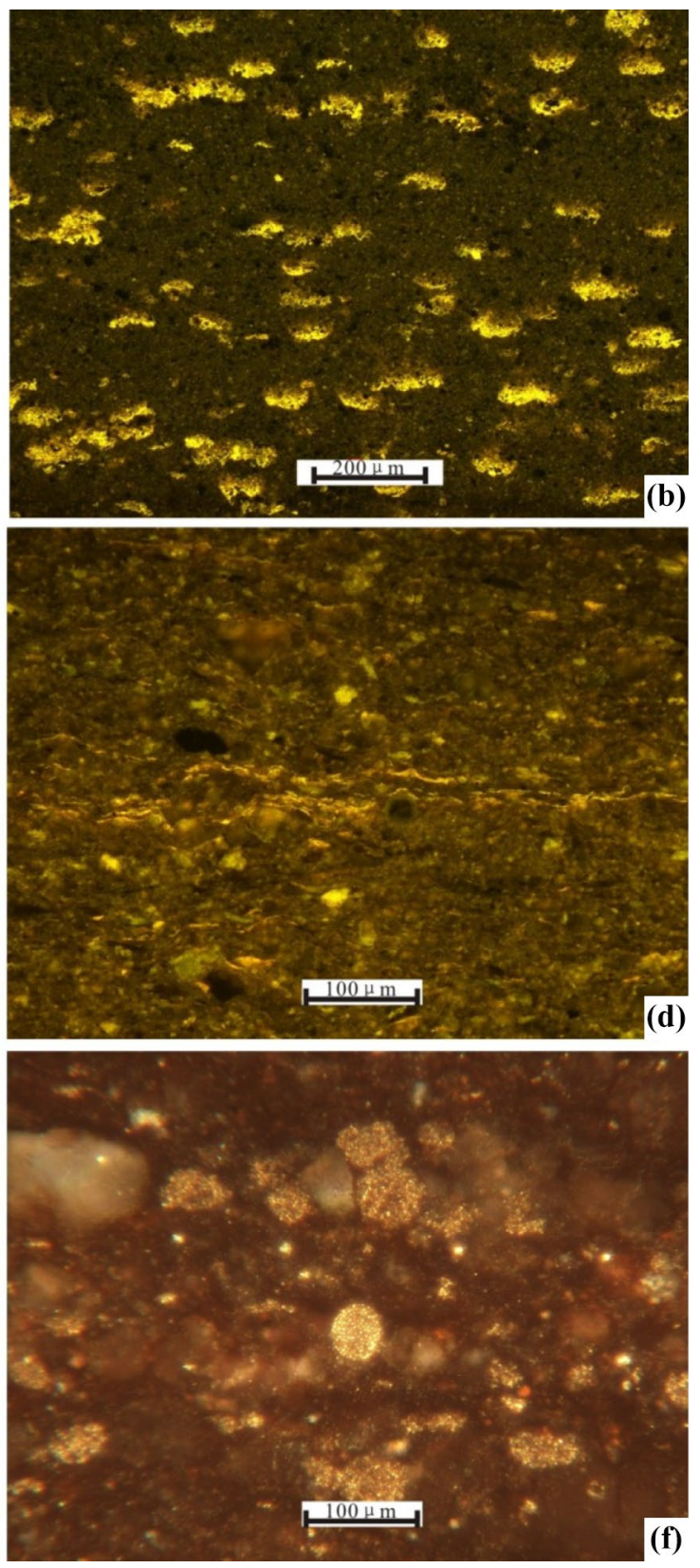

magnification, $2449.9 \mathrm{~m}$; d microlayered sporophore and liptodetrinite, $2437.21 \mathrm{~m}$; e irregular vitrodetrinite, $2439.55 \mathrm{~m}$; f pyrite in framboidal form with local concentration, suggesting reducing conditions, $2436.6 \mathrm{~m}$

\section{Advantageous shale lithofacies and effective reservoirs}

Thin sections, cores and scanning electron microscope (SEM) observation of ORI 5 in wells BYHF 1 and Cheng 2 indicate that silty shales is featured by silt laminae interbedded with clay laminae (Fig. 7a), nearly parallel fracture occurs along the adjacent area of these laminaes (Fig. 7b), and are commonly filled with secondary minerals or liquid 

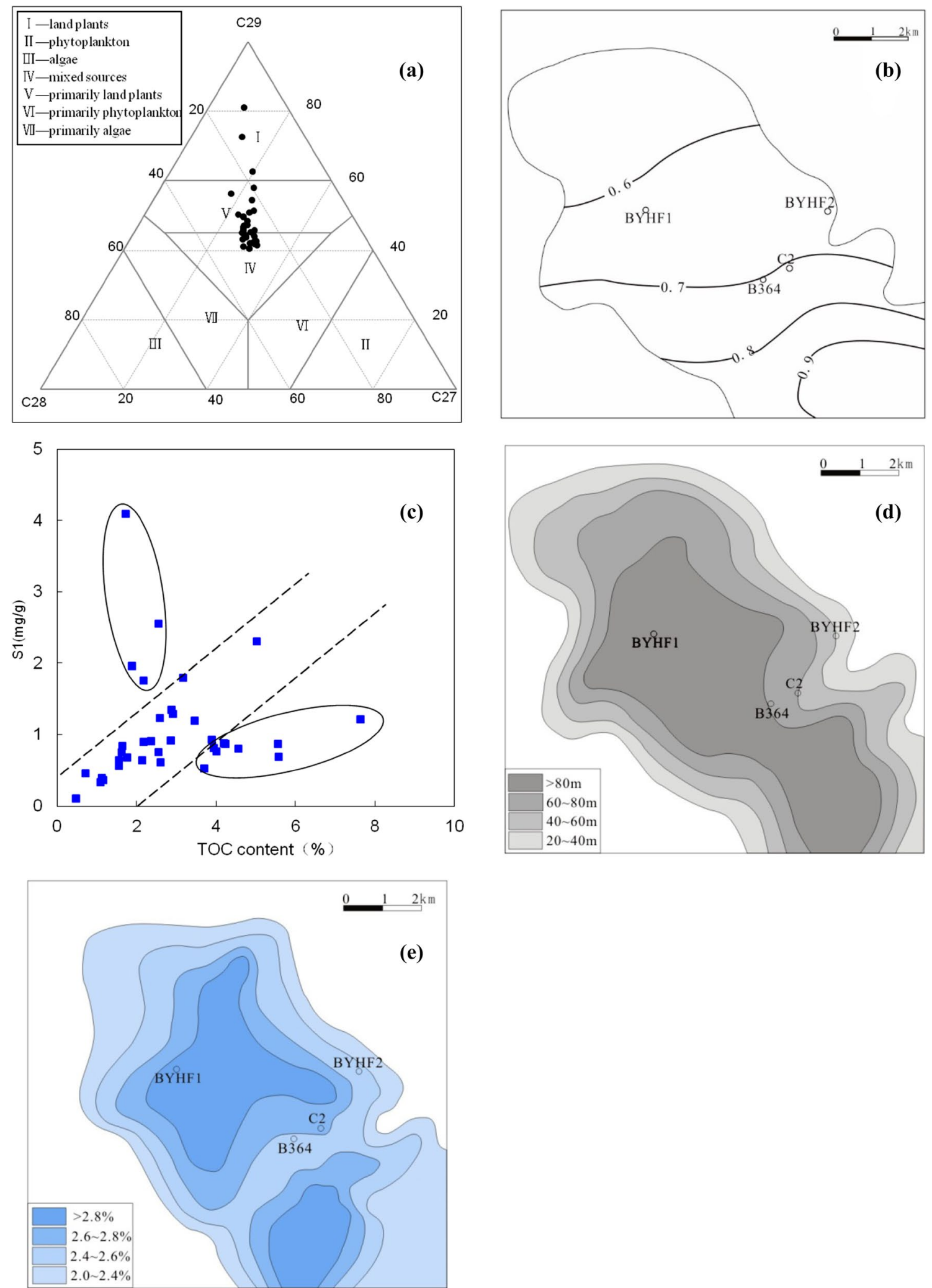

Fig. 5 a The triangular plot of biomarker parameters of core samples; $\mathbf{b} R_{\mathrm{o}}$ value isoline of ORI 5; $\mathbf{c} S_{1}$ values of majority core samples correlate positively with TOC contents; $\mathbf{d}$ thickness isoline of ORI 5; e TOC content isoline of ORI 5 
Table 1 Bulk geochemistry of the samples from well BYHF1

\begin{tabular}{|c|c|c|c|c|c|c|c|c|c|c|c|c|}
\hline \multirow[t]{2}{*}{ Sample no. } & \multirow[t]{2}{*}{ Depth (m) } & \multirow[t]{2}{*}{ TOC $(\%)$} & \multirow[t]{2}{*}{$S_{1}$} & \multirow[t]{2}{*}{$S_{2}$} & \multirow[t]{2}{*}{ HI } & \multirow[t]{2}{*}{ Bitumen "A" (\%) } & \multirow[t]{2}{*}{ OSI } & \multirow[t]{2}{*}{$R_{\mathrm{o}}(\%)$} & \multirow[t]{2}{*}{$\Phi$} & \multicolumn{3}{|c|}{$\begin{array}{l}\text { Regular steranes } \\
(\%)\end{array}$} \\
\hline & & & & & & & & & & $\mathrm{C}_{27}$ & $\mathrm{C}_{28}$ & $\mathrm{C}_{29}$ \\
\hline B-1 & 2415.72 & 0.71 & 0.46 & 2.98 & 419.72 & 0.095 & 64.79 & 0.58 & 7.29 & 26 & 26 & 48 \\
\hline B-2 & 2416.4 & 0.48 & 0.11 & 0.84 & 175 & 0.092 & 22.92 & 0.58 & 6.44 & 22 & 20 & 58 \\
\hline B-3 & 2417.46 & 1.16 & 0.36 & 2.35 & 202.59 & 0.110 & 31.03 & 0.58 & 4.22 & 8 & 10 & 81 \\
\hline B-4 & 2418.72 & 3.18 & 1.8 & 15.52 & 488.05 & 0.592 & 56.6 & 0.58 & 4.39 & 27 & 29 & 44 \\
\hline B-5 & 2419.3 & 1.76 & 0.68 & 6.57 & 373.3 & 0.310 & 38.64 & 0.58 & 3.51 & 28 & 28 & 44 \\
\hline B-6 & 2420.92 & 1.56 & 0.57 & 6.72 & 430.77 & 0.233 & 36.54 & 0.58 & 5.1 & 26 & 28 & 46 \\
\hline B-7 & 2421.65 & 2.61 & 0.61 & 12.01 & 460.15 & 0.281 & 12.37 & 0.58 & 6.19 & 24 & 26 & 50 \\
\hline B-8 & 2422.49 & 3.46 & 1.2 & 19.57 & 565.61 & 0.450 & 34.68 & 0.59 & 5.09 & 18 & 26 & 56 \\
\hline B-9 & 2423.7 & 1.56 & 0.64 & 4.31 & 276.28 & 0.202 & 41.03 & 0.59 & 6.5 & 12 & 15 & 73 \\
\hline B-10 & 2424.5 & 4.23 & 0.87 & 27.49 & 649.88 & 0.418 & 20.57 & 0.59 & 3.2 & 22 & 27 & 50 \\
\hline B-11 & 2425.72 & 3.94 & 0.81 & 23.1 & 586.29 & 0.407 & 20.56 & 0.59 & 4.28 & 28 & 27 & 45 \\
\hline B-12 & 2426.44 & 2.36 & 0.91 & 9.59 & 406.36 & 0.255 & 38.56 & 0.59 & 4.75 & 26 & 23 & 51 \\
\hline B-13 & 2427.46 & 5.56 & 0.87 & 32.94 & 592.45 & 0.284 & 15.65 & 0.59 & 5.19 & 24 & 22 & 54 \\
\hline B-14 & 2428.5 & 3.9 & 0.93 & 20.5 & 525.64 & 0.376 & 23.85 & 0.59 & 4.54 & 25 & 24 & 51 \\
\hline B-15 & 2429.83 & 1.12 & 0.39 & 2.43 & 216.96 & 0.153 & 34.82 & 0.59 & 4.28 & 20 & 18 & 63 \\
\hline B-16 & 2430.5 & 1.62 & 0.76 & 6.64 & 409.88 & 0.363 & 46.91 & 0.59 & 4.65 & 26 & 27 & 47 \\
\hline B-17 & 2431.75 & 2.58 & 1.23 & 14.23 & 551.55 & 0.467 & 47.67 & 0.59 & 4.76 & 26 & 28 & 47 \\
\hline B-18 & 2432.95 & 2.15 & 0.64 & 12.85 & 597.67 & 0.454 & 29.77 & 0.59 & 5.5 & 26 & 26 & 47 \\
\hline B-19 & 2433.64 & 5.58 & 0.69 & 34.34 & 615.41 & 0.209 & 12.37 & 0.59 & 5.18 & 31 & 27 & 42 \\
\hline B-20 & 2434.41 & 4.56 & 0.8 & 24.1 & 528.51 & 0.316 & 17.54 & 0.59 & 4.67 & 30 & 27 & 44 \\
\hline B-21 & 2435.4 & 2.92 & 1.29 & 15.1 & 517.12 & 0.848 & 44.18 & 0.59 & 4.71 & 31 & 27 & 43 \\
\hline B-22 & 2436.6 & 7.64 & 1.22 & 49.28 & 645.03 & 0.574 & 15.97 & 0.59 & 4.14 & 30 & 27 & 42 \\
\hline B-23 & 2437.21 & 5.02 & 2.31 & 15.86 & 315.94 & 1.802 & 46.02 & 0.59 & 5.37 & 31 & 28 & 42 \\
\hline B-24 & 2438.45 & 2.86 & 0.92 & 13.71 & 479.37 & 0.309 & 32.17 & 0.59 & 4.94 & 31 & 27 & 41 \\
\hline B-25 & 2439.55 & 2.18 & 0.9 & 7 & 321.1 & 0.393 & 41.28 & 0.59 & 4.81 & 29 & 26 & 46 \\
\hline B-26 & 2440.7 & 1.09 & 0.34 & 3.8 & 348.62 & 0.238 & 31.19 & 0.59 & 4.71 & 24 & 26 & 50 \\
\hline B-27 & 2441.51 & 1.64 & 0.84 & 4.05 & 246.95 & 0.362 & 51.22 & 0.59 & 4.5 & 29 & 27 & 44 \\
\hline B-28 & 2442.72 & 3.7 & 0.53 & 19.88 & 537.3 & 0.222 & 14.32 & 0.59 & 4.67 & 29 & 29 & 42 \\
\hline B-29 & 2443.65 & 2.56 & 0.76 & 11.48 & 448.44 & 0.506 & 29.69 & 0.59 & 4.65 & 26 & 28 & 46 \\
\hline B-30 & 2445.4 & 2.88 & 1.35 & 11.56 & 401.39 & 0.596 & 46.88 & 0.59 & 5.52 & 27 & 28 & 44 \\
\hline B-31 & 2445.9 & 2.56 & 2.55 & 8.93 & 348.83 & 1.098 & 99.61 & 0.59 & 3.99 & 26 & 29 & 45 \\
\hline B-32 & 2446.68 & 4.2 & 0.88 & 22.25 & 529.76 & 0.305 & 20.95 & 0.59 & 8.93 & 30 & 29 & 41 \\
\hline B-33 & 2447.86 & 1.88 & 1.96 & 7.14 & 379.79 & 0.595 & 104.26 & 0.59 & 4.82 & 27 & 30 & 43 \\
\hline B-34 & 2448.45 & 1.73 & 4.09 & 6.94 & 401.16 & 0.843 & 236.42 & 0.59 & 4.84 & 28 & 31 & 41 \\
\hline B-35 & 2449.9 & 2.17 & 1.76 & 7.15 & 329.49 & 0.800 & 81.11 & 0.59 & 5.71 & 26 & 29 & 45 \\
\hline B-36 & 2450.15 & 4.01 & 0.77 & 24.92 & 621.45 & 0.571 & 19.2 & 0.59 & 6.07 & 28 & 29 & 44 \\
\hline
\end{tabular}

$O S I$ oil saturation index $=S_{1} / \mathrm{TOC} \times 100, \mathrm{mg} \mathrm{HC} / \mathrm{g}$ TOC,$H I$ hydrogen index $=S_{2} \times 100 / \mathrm{TOC}, \mathrm{mg} \mathrm{HC} / \mathrm{g}$ TOC, $\Phi$ porosity, $\%$

The unit of $S_{1}$ and $S_{2}$ is $\mathrm{mg} \mathrm{HC/g}$ rock

hydrocarbon. Moreover, the tough quartz and feldspar contribute to slowing down the compaction, preserving interparticle pores and then providing the physical basis for shale oil storage (Fig. 7c, d). Therefore, the lithofacies association of argillaceous shales with silty shales interlayers shows high oil abundance with retained oil in the shales and migrated oil in the interbedded silty laminae, which has been demonstrated by the exploration practice in marine Jiaoshiba shale of Sichuan Basin, lacustrine Zhangjiatan shale of Ordos Basin and Kimmeridge Clay Formation of the North Sea (Raji et al. 2015; Lei et al. 2015; Guo and Zhang 2014). In addition, Zhang et al. (2015) proposed that laminated calcareous shales in the study area have the high TOC content and oil abundance, good porosity and permeability, and welldeveloped pores and fractures, particularly organic pores and dissolution pores, in which oil occured (Fig. 7e, f). Shale 
Fig. 6 The relationship between depth and acoustic time data from well BYHF 1 (a) and well B364 (b); c average formation pressure isoline of ORI 5; d well BYHF 1 correlation between overpressure, OSI and porosity values in ORI 5
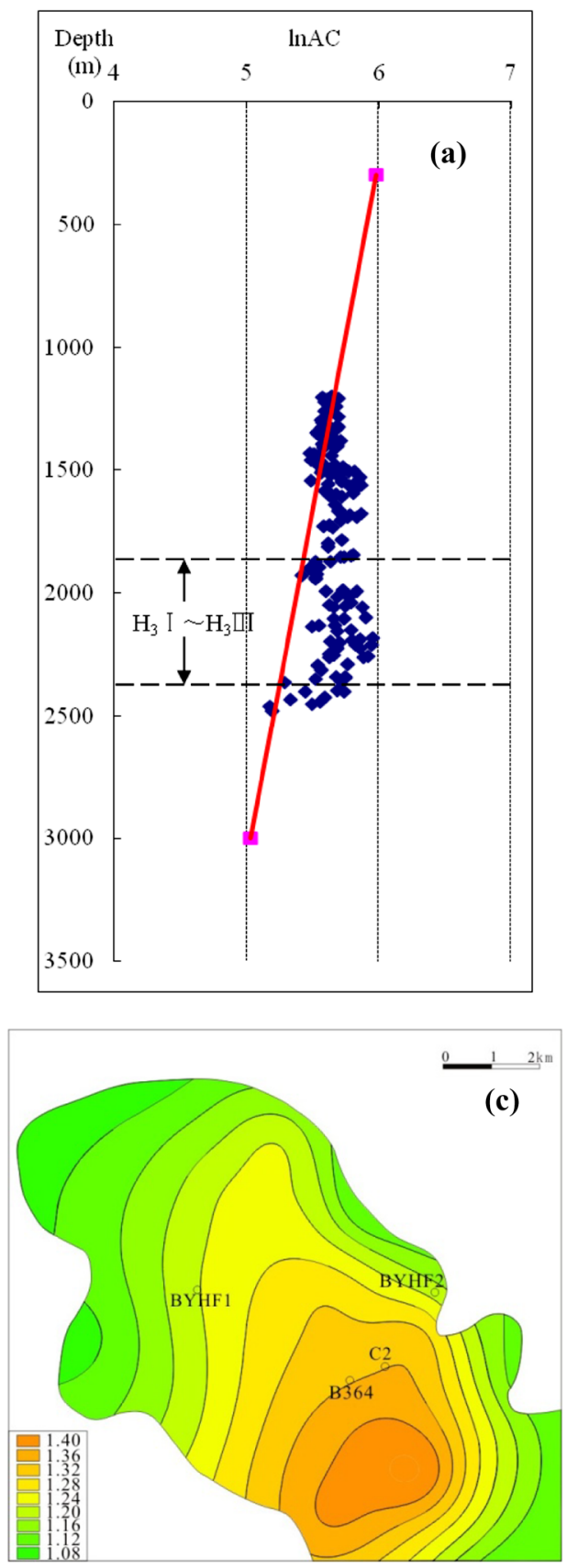
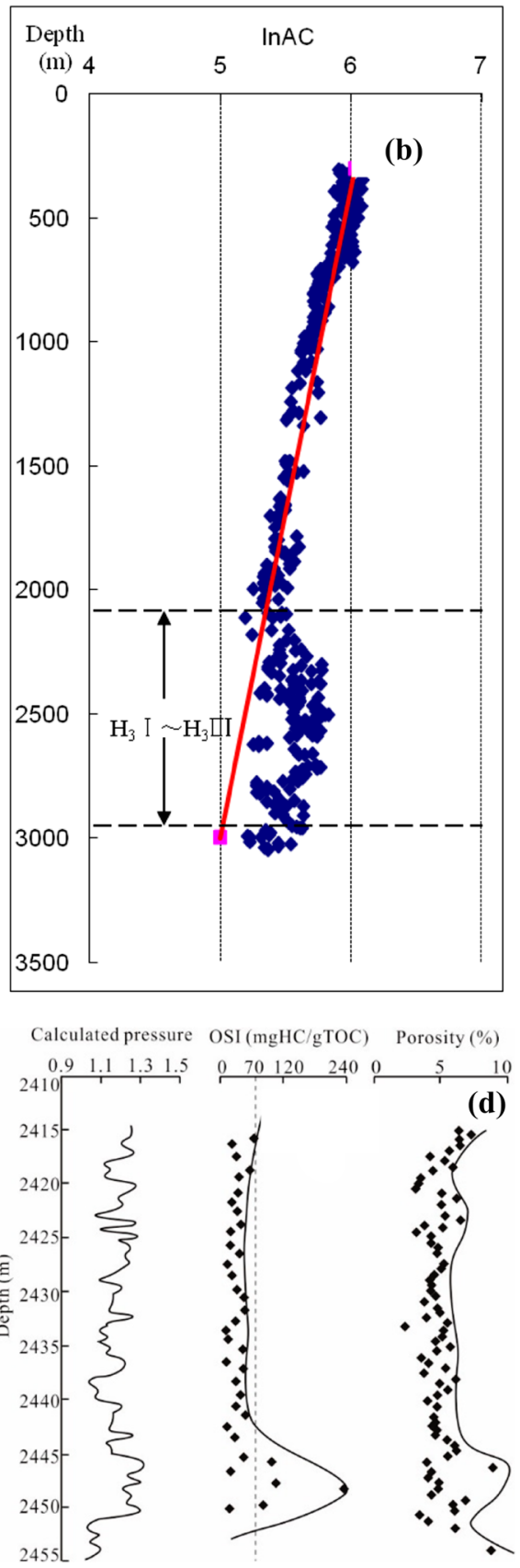

baseline is determined by Gamma-ray curve, and the values lower than the baseline level may indicate interlayers. The thickness of interlayer is 1.6-18.05 m, and mainly developed in periphery and center of deep depression (Fig. $7 \mathrm{~g}$ ).

Nie et al. (2016) proposed pore throat diameter larger than $10 \mathrm{~nm}$ benefits the storage of free oil for the continental shale in China, although the molecular diameter of medium oil with heterocyclic structure is $0.5-1.0 \mathrm{~nm}$ (Wang et al. 1996). The MICP test results show the bulk pore is composed of $28.0 \%$ of pores with diameter of $3-5 \mathrm{~nm}, 24.5 \%$ of pores with diameter of $5-10 \mathrm{~nm}, 22.5 \%$ of pores with diameter of $10-50 \mathrm{~nm}$, and $25.0 \%$ of pores with diameter larger than $50 \mathrm{~nm}$. Pores having throat diameter greater than $10 \mathrm{~nm}$ account for the majority of the bulk volume, indicating much effective reservoir space exists for shale oil storage.

Higher TOC content and maturity, and better type of organic matter are beneficial to generate much hydrocarbon, and volume expansion causes overpressure in source rock, especially in sections with low hydrocarbon expulsion efficiency due to less fractures. The ORI 5 is dominated by types $\mathrm{I}$ and $\mathrm{II}_{1}$ kerogen ( $\mathrm{Li}$ et al. 2016) and has maturities ranging from lowly to oil mature, kerogen being converted to oil tends to form overpressure. 
Fig. 7 a Silt laminae is interbedded with clay laminae from well Cheng 2, $2821.57 \mathrm{~m}$; b parallel fracture occurs along the adjacent area of the two types of laminae from well BYHF 1, $2446.5 \mathrm{~m} ; \mathbf{c}, \mathbf{d}$ hydrocarbon occurs in interparticle pores from well BYHF 1, $2427.55 \mathrm{~m}$, with cross-polarized light and fluorescence, after Zhang (2014); e, f hydrocarbon occurs in calcite dissolution pores from well Cheng 2, $2800.32 \mathrm{~m}$, with cross-polarized light and fluorescence, after Zhang (2014); g interlayer thickness of ORI 5
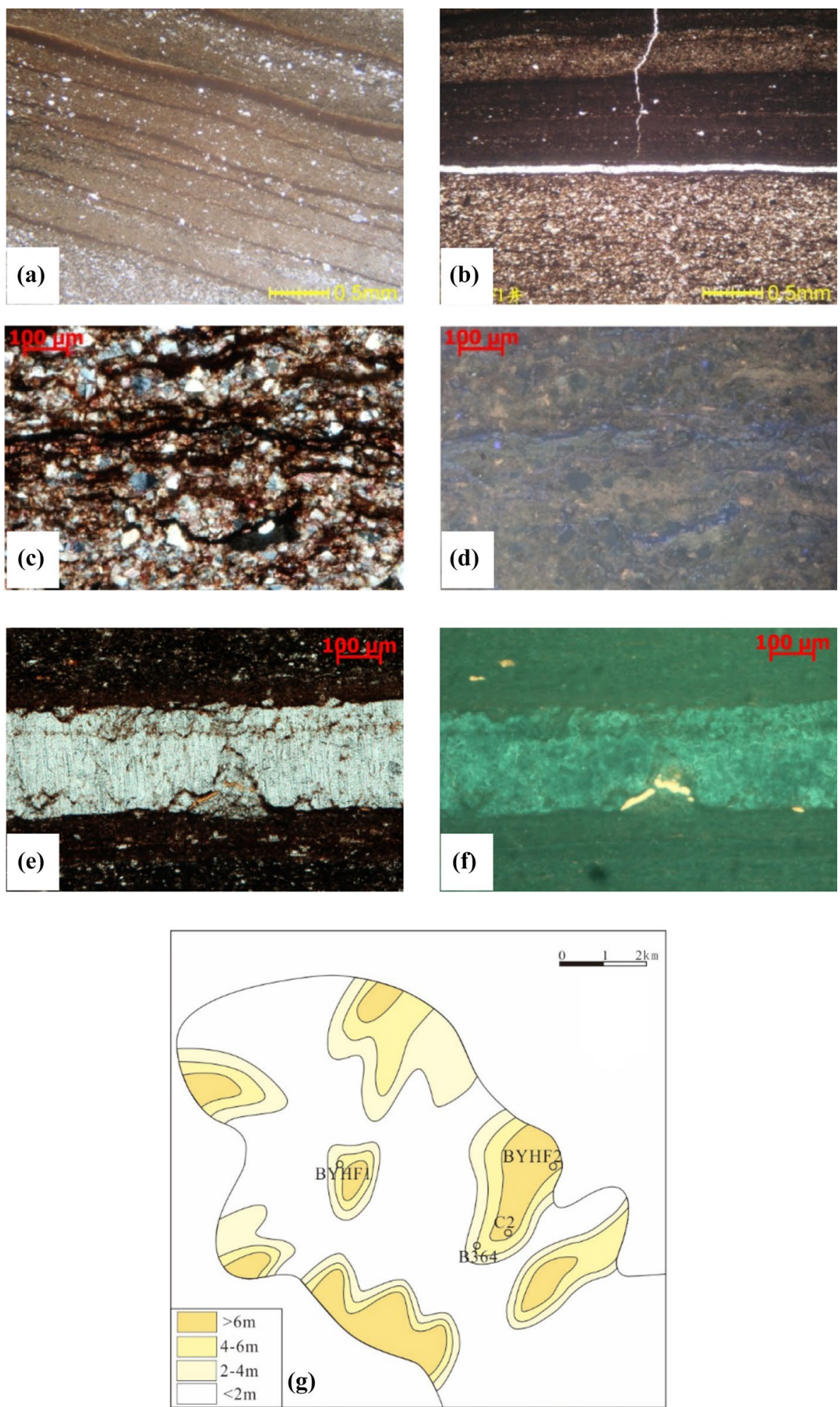

\section{Conclusions}

1. Good quality of lacustrine shale with large thickness developed in the deepest sag. Organic matter originated from higher plants and aquatic organism, and reached the oil generation threshold. $S_{1}$ values correlate positively with TOC contents.

2. The overpressure area is favorable for shale oil enrichment due to high oil retention amount and porosity. Calcareous shales and argillaceous shales with silty shale 
interlayers are well developed with better porosity and effective reservoir spaces.

Acknowledgements We thank Henan Oil Company of SINOPEC for providing samples for analysis and the reviewers for their comments that significantly improved the manuscript. This study is supported by the National Natural Science Foundation of China (Grant No. 41672136) and Key Laboratory of Tectonics and Petroleum Resources of Ministry of Education (China University of Geosciences) (Grant No. TPR-2016-11).

Open Access This article is distributed under the terms of the Creative Commons Attribution 4.0 International License (http://creativeco mmons.org/licenses/by/4.0/), which permits unrestricted use, distribution, and reproduction in any medium, provided you give appropriate credit to the original author(s) and the source, provide a link to the Creative Commons license, and indicate if changes were made.

\section{References}

Guo TL, Zhang H (2014) Formation and enrichment mode of Jiaoshiba shale gasfield, Sichuan Basin. Pet Explor Dev 41(1):31-40

Jiang ZX, Zhang WZ, Liang C et al (2014) Characteristics and evaluation elements of shale oil reservoir. Acta Pet Sin 35(1):184-196

Lei YH, Luo XR, Wang ZZ et al (2015) Characteristics of silty laminae in Zhangjiatan Shale of southeastern Ordos Basin, China: implications for shale gas formation. AAPG Bull 99(4):661-687

Li SF, Hu SZ, Xie XN et al (2016) Assessment of shale oil potential using a new free hydrocarbon index. Int J Coal Geol 156:74-85

Liu B, Lvu YF, Zhao R et al (2012) Formation overpressure and shale oil enrichment in the shale system of Lucaogou Formation, Malang Sag,Santanghu Basin, NW China. Pet Explor Dev 39(6):699-705

Meinschein WG, Huang WY (1981) Sterols, stanols, steranes, and the origin of natural gas and petroleum. In: Atkinson G, Zuckerman
JL (eds) Origin and chemistry of petroleum. Pergamon Press, Oxford, pp 33-35

Nie HK, Zhang PX, Bian RK et al (2016) Oil accumulation characteristics of China continental shale. Earth Sci Front 23(2):55-62

Raji M, Gröcke DR, Greenwell HC et al (2015) The effect of interbedding on shale reservoir properties. Mar Pet Geol 67:154-169

Shang F, Liu ZJ, Xie XN et al (2015) Organic matter accumulation mechanisms of shale series in He-third member of Eocene Hetaoyuan formation, Biyang Depression, eastern China. Pet Sci Technol 33(13-14):1434-1442

Shang F, Liu ZJ, Xie XN (2016) Application of well logs prediction method for organic carbon content in Biyang Sag, Nanxiang Basin. Xinjiang Pet Geol 37(1):102-106

Song GQ, Zhang LY, Lu SF et al (2013) Resource evaluation method for shale oil and its application. Earth Sci Front 20(4):221-228

Wang XZ, Song YT, Wang XJ (1996) Petroleum generation and expulsion physical simulation: method, mechanism and application. China University of Petroleum Press, Dongying

Zhang WZ (2014) Characteristics and evaluation factors of shale oil reservoir of the third member of Hetaoyuan Formation, Palaeogene in Biyang Depression. Dissertation, China University of Geosciences (Beijing)

Zhang XW, Wang YX, Wang GL et al (2015) Reservoir characteristics of lacustrine shale oil of the Paleogene Hetaoyuan Formation in Biyang Sag of Nanxiang Basin, Henan Province. J Palaeogeogr 17(1):107-118

Zou CN, Yang Z, Cui JW et al (2013) Formation mechanism, geological characteristics and development strategy of nonmarine shale oil in China. Pet Explor Dev 40(1):14-26

Zou CN, Zhu RK, Bai B et al (2015) Significance, geologic characteristics, resource potential and future challenges of tight oil and shale oil. Bull Mineral Pet Geochem 34(1):3-17

Publisher's Note Springer Nature remains neutral with regard to jurisdictional claims in published maps and institutional affiliations. 